European journal of American studies

16-4 | 2021

The American Neuronovel (2009-2021)

\title{
Introduction
}

\section{Pascale Antolin}

\section{Q OpenEdition}

\section{Journals}

Electronic version

URL: https://journals.openedition.org/ejas/17454

DOI: 10.4000/ejas.17454

ISSN: 1991-9336

\section{Publisher}

European Association for American Studies

\section{Electronic reference}

Pascale Antolin, "Introduction", European journal of American studies [Online], 16-4 | 2021, Online since 20 December 2021, connection on 07 July 2022. URL: http://journals.openedition.org/ejas/17454 ; DOI: https://doi.org/10.4000/ejas.17454

This text was automatically generated on 7 July 2022 .

\section{(c) (1) \$}

Creative Commons - Attribution-NonCommercial 4.0 International - CC BY-NC 4.0 https://creativecommons.org/licenses/by-nc/4.0/ 


\title{
Introduction
}

\author{
Pascale Antolin
}

The novel is an excellent genre for pushing the scientific imagination into new places.

(Dennett 160)

1 “'So far the votes are two Asperger's, one probable OCD, and one possible ADHD"' (97), says Theo Byrne, the first-person narrator of Richard Powers's Bewilderment, as he ironically refers to the different diagnoses given by doctors for his son's eccentric cognitive dispositions. Bewilderment, published in September 2021, is Powers's latest novel, and probably the last American neuronovel published in 2021. Another instance of the idiosyncratic "hybrid fiction" which Powers has been writing and claiming for years, the book combines neurodivergence and neurotherapy with a strong environmental commitment, and the neuronovel with both ecological fiction and science fiction. ${ }^{2}$

2 Bewilderment, therefore, testifies to the contemporary neuronovel's difference and distance from the narrow definition of the genre, or sub-genre, given by Marco Roth in 2009. Roth coined the word to decry the transformation, since 1997 he said, of "the novel of consciousness or the psychological or confessional novel-the novel, at any rate, about the workings of a mind-... into the neurological novel, wherein the mind becomes the brain." The American critic could hardly have imagined at the time that the derogatory label would become so influential. Over the years a number of scholars have highlighted both the limitations of Roth's analysis and the limits of the word neuronovel; however, most end up using it anyway, probably for the sake of simplicity. Why has it been so popular? Is it because of its "slick sound," as Stephen Burn puts it ("Gender"), or the trendiness of the prefix neuro- since the 1990s-declared the "the Decade of the Brain" by President George H.W. Bush? It is hard to tell. "Neuronarrative," suggested by Gary Johnson in 2008 to describe "a work of fiction that has cognitive science as a, or the, main theme" (170), uses the same prefix and could have been more convenient, as it embraces short fiction and life writing as well. Other labels have also been coined: "cognitive fiction" (Tabbi 2002), "neurological realism" (Harris 2008), "syndrome novel" (Lustig and Peacock 2013), and "brain narratives" 
(Tougaw 2018). None of them, however, has been anywhere near as successful as neuronovel to refer to the fiction involving brain science and/or brain disorders.

Late in 2021, that is, twelve years after the emergence of the neologism, the field has been extensively mapped as a number of books, articles and special issues of academic journals have been published. The word neuronovel is no longer disparaging, but merely descriptive, and the definition has been considerably expanded. For instance, while Jason Tougaw introduces the brain memoir into neuro-literature, he also includes both plot and formal strategies in the definition: "Brain memoirs and so-called neuronovels conceive the physical brain as central to the stories they tell, the conflicts they plot, and the characters they portray; both genres engage brain research, translating neurobiological theories into literary experiments" (Elusive Brain 3). As for Burn, he argues that the neuronovel appeared well before 1997 and introduces Don DeLillo's early fiction-Great Jones Street (1973) and Ratner's Star (1976) -into brain-based literary studies: "Some of the most revealing syndrome novels, in fact, are those that do not foreground cognitive models at the level of plot, but instead offer suggestive hints of their neural narratives through an author's formal and rhetorical choices or through carefully placed allusions that lie at the ragged edges of the central character's lives" ("Mapping" 36). Among the precursors to the contemporary genre, Francis Ortega and Fernando Vidal include science fiction novels-Philip Dick's A Scanner Darkly (1977), for instance-and medical thrillers from the seventies (334-336). Tougaw also mentions amnesia fictions, a tradition with a long history going back to William Shakespeare ("Amnesia Narratives"). The neuronovel, therefore, is not an orphan that suddenly came to life with the neuro-technological revolution in the last decade of the twentieth century. It belongs in a long lineage of fiction narrated by or through cognitively impaired characters (Tougaw, Elusive Brain 131).

4 It is true that in the last fifty years or so the development of neuroscience, as a result of a wide spectrum of neuroimaging technologies, has led to a "paradigm shift in our understanding of the world and of ourselves" (Lustig and Peacock 5). Neural theories of mind have developed explaining mental phenomena in terms of brain processes. They propound that our very nature as human beings is shaped by the structure and functions of our brains. Some speak of a "neuroscientific turn" (Littlefield and Johnson 2012) and the emergence of neuroculture, others, more critically, of the development of "neuromania" (Satel and Lilienfield 2013). As early as the 1990s, popular books using the findings of neuroscience were published and soon became bestsellers: the most famous included philosopher Daniel Dennett's Consciousness Explained (1991) and psychologist Stephen Pinker's How the Mind Works (1997). The major tenets of contemporary neurobiology have often been encapsulated in popular and provocative, aphoristic sentences, like the famous "you are your brain." Among the more recent, "our brains hold the key to whom we are" and "mind is what brain does" are good examples (Rose and Abi-Rached 1, 3). According to Roth, neuronovelists display, even defend, these reductionist principles. While Roth's identification of the emerging genre, was very perceptive in 2009 , he actually misinterpreted the new fiction. Neuronovelists certainly "illustrate the contemporary fascination with both the workings and the sciences of the mind" (Reiffenrath 2). However, they also express their concerns about "the biologization of the self and the medicalization of the mind" (Waugh 25). What they actually do, Tougaw writes, is "play with biology to experiment with literary form; they include physiology as a category of human experience, and they explore the mysteries inherent in the fact that we are physical creatures whose 
brains play unknown roles in the making of our fantasy lives, our sense of self, our feelings, our identities, and consciousness" ("12 Great Books"). Neuronovelists may even be attracted to the authoritative, empirical language of neuroscience. Introducing this language into their narratives may be an attempt to appropriate even master its power, and it has certainly contributed to the regeneration of their fiction.

Whatever the authors' personal motivations, neurofiction engages with contemporary theories of being. It participates in the current debates about neurocognitive difference and raises ethical questions about the representation of neurological difference. It also illustrates the medicalization of the mind since the first edition of the Diagnostic and Statistical Manual of Mental Disorders (DSM-I) in 1952. According to Patricia Waugh, however, it was in 1980 with the publication of DSM-III that the "biomedical syndrome" emerged and "the Age of the Syndrome began." Since then, she argues, "mental illnesses [have been] diseases of the brain or central nervous system" (Waugh 18). The emergence of neurological syndromes in the social arena has resulted in the development of syndrome novels on the literary stage. However, it has not increased the stigmatization of neurodivergence. Instead, it has made neurological difference more familiar and contributed to "dethrone simplistic myths about 'cerebral subjectivity' and neurotypicality" (Tougaw, Elusive Brain 38). For Burn, the neuronovel also "stands as a synecdoche for the larger sense of disorientation that haunts millennial life" ("Mapping" 43). As neurodivergent characters make the familiar strange, they question the meaning of modernity. They also challenge conventional categories-disability and health, in particular-and representations, whether social or literary.

However, neuronovels are often more conventional than the experimental fiction characteristic of Postmodernism. The new genre returns to character and the subjective point of view-through first-person narratives or third-person narratives using internal focalization. The neuronovel also gives a voice to brain-impaired protagonists, "thus recovering the patient's voice that is generally absent from scientific, including neuroscientific writing" (Ortega and Vidal 332). In popular science writing like Oliver Sacks's or V. S. Ramachandran's, by contrast, the doctor's experience and voice prevail. The dominance of the first-person perspective in the new genre is an illustration of literature's fundamental connection to subjective experience, which is always singular. By contrast, neuroscience is concerned with "general explanatory laws which apply universally" (Lodge 10). Waugh even contends that the neuronovel is "part of a project to rescue the singularity of human experience from phantom objectivity" (24). Focusing on subjective experience is also a means for neuronovelists to highlight the "explanatory gap," 3 that is, the gap between objective neural networks and subjective experience, or consciousness. This is a major question that neuroscience has failed to answer so far despite its self-confident rhetoric. It has also been unable to account for the complex relations among body, mind, self and world. In Man Walks into a Room (2002), for instance, Nicole Krauss takes advantage of her character's amnesia to create entire paragraphs luxuriating in the small details of everyday life, even bodily experience. This is a strategy of resistance to the overbearing authority of neuroscience. In this sense, the neuronovel enacts a defense of literature as a counternarrative to the dehumanized language of brain science.

7 Returning to more conventional narrative forms, the neuronovel also returns to traditional genres-detective fiction in particular (Tougaw, Elusive Brain, 132-135). Most 
contemporary neuronovels actually borrow from and challenge conventional genres. In The Unnamed (2010) for instance, Joshua Ferris uses detective fiction as a subplot, however, his narrative brings together the neuronovel, the naturalist novel and $19^{\text {th }}$ century poetry. ${ }^{4}$ As for Krauss, she only uses the detective story as a red herring in the opening pages of her book. The generic pattern that she relies on throughout is the coming-of-age novel and its characteristic journey. However, her narrative also consists of a series of episodes, each associated with one particular genre: science fiction, the horror story, the Katabasis narrative and the quest. Like the coming-of-age narrative, all are equally distorted. Through generic manipulations and other formal experiments, neuronovels display the novel's plasticity, and its dialogic ability to combine the old and the new, traditional conventions with contemporary experimentations. Neurofiction especially generates a dialogue between neuroscience and literature, sometimes even between neuroscience and spirituality-with Ferris's The Unnamed as a good example again. In 2021, therefore, the neuronovel (or syndrome novel) is able to emerge as a "textual syndrome," to take up Tom LeClair's phrase, ${ }^{5}$ as he relies on the etymology of syndrome, that is, "a place where several roads meet."

8 The essays in this special issue certainly confirm this interpretation: some identify dialogues with brain science in narratives where we may be surprised to find such engagements; others create new dialogues between works involved with neurodivergence. Stephen Burn and Jason Tougaw, for instance, are concerned with the precursors to the contemporary neuronovel and approach the genre from brand-new angles: Burn focuses on "gender asymmetry" in the neuronovel, and Tougaw analyzes amnesia narratives. While Joyce Carol Oates has never been mentioned as a neuronovelist, Burn's analysis of her writing between 1971 (Wonderland) and 2016 (The Man Without a Shadow) allows him to highlight both Oates's engagement with brain research and the limitations of the label neuronovel again. Tougaw focuses on fiction and nonfiction amnesia narratives from different periods, and highlights some major elements they share, including the close connection between memory and forgetting, and the more elusive relation between memory and identity. My own essay on Nicole Krauss's Man Walks into a Room is also concerned with amnesia but the protagonist clearly challenges the memory-identity equation. As Krauss emphasizes subjective experience and the explanatory gap, she writes a brain novel against brain science and reductionism. Her generic experimentations are far more successful than her (mad) scientist's brain experiments so that her novel ultimately emerges as a display of the power of literature. The last two essays by James Peacock and Bonnie Cross also share a common characteristic: they offer highly fruitful comparisons between brain narratives. Peacock returns to Motherless Brooklyn (1999) by Jonathan Lethem, ${ }^{6}$ but develops a comparison between Lethem's detective and Paul Tremblay's in The Little Sleep (2009). Peacock first shows the close connection between the protagonists' conditions and their urban neighborhoods, Brooklyn for one, and South Boston for the other. He also underlines the role of cars in both novels: as they facilitate physical and metaphorical mobility, they allow the detectives to escape the confines both of their communities and their conditions. Bonnie Cross compares a neuronovel, The Echo Maker (2006) by Richard Powers, with a brain memoir, Brain on Fire (2012) by Susannah Cahalan, and shows how in the fiction and the memoir alike, the characters suffering from rare brain conditions can no longer rely on their own perceptions of selfhood. The two narratives, therefore, combine the different perspectives that help the sick protagonists regain a coherent sense of self. 
9 Taken together, the essays in this special issue confirm that the field of the neuronovel has already been mapped but it has not been fully explored. They may also suggest a reason for the success of the word neuronovel: could it not simply derive from the beneficial defamiliarization of the old stem novel with the addition of the prefix neurofollowing the principle of "estranging kinship" defended by Powers (Michod), especially in a period of neuromania? Scholars and ordinary readers alike certainly enjoy, may even need, "that overlap between self-composure and total, alien bewilderment" (Michod) that fiction plays on, and neurofiction even more. As Charles B. Harris explains about Richard Powers, although his statement certainly applies to all neuronovelists, "by immersing [their] readers in the defamiliarizing world of contemporary brain science [and neurodivergence], [the neuronovelist] troubles our complacent assurance that the self is solid and continuous, unsettling our certainties in order to open the stories of our life to the multiple stories around us" (Harris 252).

\section{BIBLIOGRAPHY}

Burn, Stephen J. "Mapping the Syndrome Novel." Diseases and Disorders in Contemporary Fiction: The Syndrome Syndrome, edited by T. J. Lustig and James Peacock, Routledge, 2013, pp. 35-52.

Dennett, Daniel C. "Astride the Two Cultures: A Letter to Richard Powers, Updated." Intersections: Essays on Richard Powers, edited by Stephen J. Burn and Peter Dempsey, Dalkey Archive P, 2008, pp. 151-161.

Johnson, Gary. "Consciousness as Content: Neuronarratives and the Redemption of Fiction." Mosaic, vol. 41, pp. 169-184.

Harris, Charles B. "The Story of the Self: The Echo Maker and Neurological Realism." Intersections: Essays on Richard Powers, edited by Stephen J. Burn and Peter Dempsey, Dalkey Archive P, 2008, pp. 230-259.

LeClair, Tom. "The Unnamed." Review of The Unnamed by Joshua Ferris, Barnes and Noble Review, 18 Jan 2010. https://www.barnesandnoble.com/review/the-unnamed. Accessed 3 Nov 2021.

Levine, Joseph. “Materialism and Qualia: The Explanatory Gap.” Pacific Philosophical Quarterly, vol. 64, October 1983, pp. 354-361.

Littlefield, Melissa M., and Jenell M. Johnson, editors. The Neuroscientific Turn: Transdisciplinarity in the Age of the Brain. $\mathrm{U}$ of Michigan P, 2012

Lodge, David. Consciousness and the Novel [2002]. Vintage, 2018.

Lustig, T. J., and James Peacock. "Introduction." Diseases and Disorders in Contemporary Fiction: The Syndrome Syndrome, edited by T. J. Lustig and James Peacock, Routledge, 2013, pp. 1-16.

Michod, Alec. "The Brain Is the Ultimate Storytelling Machine, and Consciousness Is the Ultimate Story." An Interview with Richard Powers. Believer 41, 1 Feb 2007, https://believermag.com/aninterview-with-richard-powers/. Accessed 4 Nov 2021.

Powers, Richard. Bewilderment. W.W.W. Norton \& Company, 2021. 
Reiffenrath, Tanja. “Mind over Matter? Joshua Ferris's The Unnamed as Counternarrative." Literary Refractions, vol. 5, no. 1, December 2014, pp. 1-20.

Roth, Marco. "The Rise of the Neuronovel." $n+1$, issue 8: Recessional, Fall 2009, https:// nplusonemag.com/issue-8/essays/the-rise-of-the-neuronovel/. Accessed 4 Nov 2021.

Rose, Nikolas, and Joelle M. Abi-Rached. Neuro: The New Brain Sciences and the Management of the Mind. Princeton UP, 2013.

Satel, Sally, and Scott O. Lilienfield. Brainwashed. The Seductive Appeal of Mindless Neuroscience. Basic Books, 2013.

Sun, Jian. "Fictional Collisions: Richard Powers on Hybrid Narrative and the Art of Stereoscopic Narrative." Critique: Studies in Contemporary Fiction, vol. 54, no. 4, 2013, pp. 335-345.

Tabbi, Joseph. Cognitive Fictions. U of Minnesota P, 2002.

Tougaw, Jason. "12 Great Books About the Human Brain.” Electriclit 9 Oct 2017. https:// electricliterature.com/12-great-books-about-the-human-brain/. Accessed 24 Oct 2021.

---. The Elusive Brain: Literary Experiments in the Age of Neuroscience. Yale UP, 2018.

Waugh, Patricia. "The Naturalistic Turn, the Syndrome, and the Rise of the NeoPhenomenological Novel." Diseases and Disorders in Contemporary Fiction: The Syndrome Syndrome, edited by T. J. Lustig and James Peacock, Routledge, 2013, pp. 17-34.

\section{NOTES}

1. The label was coined by Daniel Grassian in 2003 and claimed by Powers in a 2013 interview, "Fictional Collisions: Richard Powers on Hybrid Narrative and the Art of Stereoscopic Narrative."

2. The novel is said to draw inspiration from Daniel Keyes's famous science fiction story and novel, Flowers for Algernon, published respectively in 1959 and 1966.

3. The explanatory gap was first conceptualized by Joseph Levine in a 1983 essay, "Materialism and Qualia: The Explanatory Gap."

4. Emily Dickinson's poem "After great pain, a formal feeling comes-" structures the narrative, as all the novel's chapter titles are borrowed from the poem.

5. LeClair merely refers to Ferris's The Unnamed, but "textual syndrome" seems to me a very good label for any neuronovel.

6. See “'We learned to tell our story walking': Tourette's and Urban Space in Jonathan Lethem's Motherless Brooklyn" in Diseases and Disorders in Contemporary Fiction (2013), edited by T. J. Lustig and James Peacock (67-82).

\section{AUTHOR}

\section{PASCALE ANTOLIN}

Pascale Antolin is Professor of American literature at Bordeaux Montaigne University and head of the research group CLIMAS. A specialist of American Modernism and Naturalism, she has 
published books and articles on F. Scott Fitzgerald, Nathanael West, Frank Norris and Stephen Crane: e.g. L'Objet et ses doubles. Une relecture de Fitzgerald (Presses universitaires de Bordeaux, 2000); Nathanael West. Poétique de l'ecchymose (Belin, Paris, 2001). For several years now, she has focused her research on illness in literature and published numerous articles on the subject in French, European and American journals. Recently, she has developed a special interest in the neuronovel, and published several essays, a book chapter, and a Wiley encyclopedia entry on brain fiction. 